\title{
A veleszületett immunitás vizsgálata Drosophila melanogasterben
}

\author{
Ph.D. értekezés tézisei
}

Kari Beáta

Témavezető: Dr. Kurucz Judit Éva

Biológia Doktori Iskola

MTA Szegedi Biológiai Kutatóközpont

Genetikai Intézet

Szegedi Tudományegyetem Természettudományi

és Informatikai Kar

2016.

Szeged 


\section{Bevezetés}

A veleszületett immunitás a többsejtű szervezetek legősibb védekező mechanizmusa, melynek több funkcionális egysége is megőrződött az evolúció során, ezért vizsgálatában az ecetmuslica (Drosophila melanogaster) az egyik leggyakrabban használt gerinctelen modellszervezet. A veleszületett immunitás két részből, a szolubilis faktorok kibocsátásán alapuló humorális immunválaszból, és az immunsejtek által végrehajtott sejt-közvetítette immunválaszból tevődik össze. A humorális immunválasz során kibocsájtott faktorok vagy közvetlenül pusztítják el a kórokozókat vagy pedig a sejt-közvetítette immunitást segítve játszanak szerepet a védekezésben. A sejt-közvetítette immunválasz végrehajtó elemei a hemociták, amelyek a kórokozók fagocitózisát végzik, valamint nagyméretü parazitoidok körül, mint amilyen a fürkészdarazsak petéje, többrétegü tokot képeznek.

A patogénekkel a gazdaszervezetek a védekezési mechanizmusok széles skálájával veszik fel a versenyt. A gazdaszervezetek és a kórokozók közötti kölcsönhatás során a parazitákra illetve patogén mikroorganizmusokra ható szelekciós nyomás következtében olyan virulens törzsek alakulhatnak ki, amelyek különböző stratégiáikkal kikerülik a gazdaszervezet védekezési folyamatait.

Munkánk során a Drosophila szeptikus sérülése által kiváltott védekezési rendszerének vizsgálatára egy olyan új in vivo módszert dolgoztunk ki, amely a természetben is előforduló sérülést laboratóriumi körülmények között modellezi és

lehetővé teszi olyan új faktorok azonosítását, amelyek szerepet játszanak a szeptikus sérülést követő védekező reakciókban és ezáltal biztosítják az egyed túlélését. A kidolgozott módszerünk felhasználásával egy irányított screent 
végeztünk. A screen során azonosított, az immunvédekezésben szerepet játszó raspberry szerepét vizsgáltuk a tokképzésben.

\section{Célkitüzések}

Kísérleteink során a következő célokat tüztük ki:

1. Egy, a természetben is előforduló szeptikus sérülést imitáló modell kidolgozását, amely alkalmas a fertőzések elleni védekezésben résztvevő gének azonosítására, a mikróbák patogenitásának meghatározására és antimikrobiális szerek in vivo körülmények között történő tesztelésére.

2. Egy olyan modell létrehozását, amelynek eredményei reprodukálhatóak, továbbá könnyen kivitelezhető és tömeges vizsgálatokra is alkalmas.

3. A szeptikus sérülési modell validálását ismert aktivációs utak és standard baktériumtörzsek segítségével.

4. Egy irányított screen elvégeztzését eddig ismeretlen védekezési útvonalak azonosítására.

5. A védekező reakció - vizsgáló rendszerünk segítségével azonosított - egyik új elemének, a Drosophila sejt-közvetítette immunválaszában játszott szerepének jellemzését. 


\section{Alkalmazott módszerek}

Módszerünkben a sérülést úgy hoztuk létre, hogy az ecetmuslicák első pár lábának tarsális ízeit eltávolítottuk, az állatokat baktérium pázsitra helyeztük, majd vizsgáltuk az egyes Gram-negatív (Escherichia coli és Serratia marcescens), és Gram-pozitív (Bacillus cereus var. mycoides) baktériumok túlélésre gyakorolt hatását.

GFP riporter fehérjét termelö $E$. coli felhasználásával vizsgáltuk a baktériumok bejutását az okozott lábsérülésen keresztül.

Megvizsgáltuk a steril sérülés hatását az ecetmuslicák életképességére.

Módszerünk validálását olyan gének mutáns alléljait hordozó ecetmuslicákon teszteltük, amely gének a humorális immunválasz Toll és Imd jelátviteli útvonalaiban vesznek részt.

Vizsgáltuk a módszer alkalmazhatóságát antimikrobiális hatású anyagok tesztelésére.

Szeptikus sérülési tesztünk felhasználásával, az immunvédekezésben szerepet játszó gének azonoítására, egy irányított screent végeztük. Ennek során olyan gének mutáns alléljait hordozó ecetmuslicák életképességét vizsgáltuk, amelyeknek irodalmi adatok alapján szerepük lehet a bakteriális fertőzés leküzdésében.

A srceen során azonosított raspberry szerepét a fagocitózisban in vitro és áramlási citometriával vizsgáltuk.

A raspberry szerepét a tokképzésben Leptopolina boulardi G486 parazitoid darázs fertőzést követően jellemeztük a ras $^{2}$ hipomorf mutánsban és a raspberry géntermék vérsejt-specifikus RNS interferenciával történő csendesítését követően. A parazitoid darázspeték körül képződött tok szerkezetét a lárvák boncolását követően határoztuk meg. A hemociták morfologiájának és a filopódiummal 
rendelkező vérsejtek arányának meghatározásához immunfluoreszcens jelölést és fluoreszszens mikroszkópot használtunk.

\section{Eredmények}

1. Kidolgoztunk egy új szeptikus sérülési modellt Drosophilában, amely a természetes élőhelyen is előforduló sérülést modellezi, eredményei reprodukálhatóak, továbbá könnyen kivitelezhető és tömeges vizsgálatokra is alkalmas.

2. A módszer alkalmazható a patogén-gazdaszervezet kölcsönhatásokban, a kórokozókkal szembeni védelemben, a koagulációban, sebgyógyulásban szerepet játszó gének azonosítására, valamint a mikróbák patogenitásának vizsgálatára és különböző anyagok antimikrobiális hatásának in vivo tesztelésére.

3. GFP-t termelő Escherichia coli baktérium felhasználásával kimutattuk, hogy a baktériumok az okozott sérülésen keresztül jutnak be az állatok testüregébe. A sértetlen és sérült állatok Gram-negatív Serratia marcescens és Escherichia coli, valamint Gram-pozitív Bacillus cereus var. mycoides baktériumfertőzése azt mutatta, hogy az ecetmuslicák pusztulását minden esetben az okozott sérülésen keresztül bejutó mikroorganizmusok váltották ki.

4. Módszerünket a humorális immunválaszban már ismert szerepet játszó gének mutáns alléljait tartalmazó Drosophila törzsek felhasználásával validáltuk.

5. A Hemolectin mutánssal kapott eredményeink rávilágítottak arra, hogy a Hemolectinnek nemcsak a lárva hemolimfa koagulációjában, hanem az adult ecetmuslica véralvadásában is fontos szerepe van. 
6. Szeptikus sérülési modellünk felhasználásával, egy irányított screen során, az immunválaszban szerepet játszó új géneket is azonosítottunk, többek között a Drosophila inozin-monofoszfát-dehidrogenáz (IMPDH) enzimet kódoló a raspberry gént, amely a GMP szintézis kulcsenzime.

7. Eredményeink szerint a raspberry részt vesz az adult ecetmuslicák szeptikus sérülését követő baktériumfertőzés leküzdésében, valamint a lárva parazitoid darázsfertőzést követő sejt-közvetítette immunválaszában, a tokképzésben. Kísérleteink során azt tapasztaltuk, hogy a L. boulardi G486 által fertőzött raspberry mutáns bábokból, valamint a raspberry gén hemocita specifikus csedesítését követően kifejlődött bábokból szignifikánsan több darázs kelt ki, mint a vad típusú Oregon- $R$ esetében. A darázzsal fertőzött lárvákban csökkent a teljesen melanizált darázspeték száma és megemelkedett a laza szerkezetű tokok aránya a kontrollokhoz képest. Ez arra utal, hogy a raspberry gén által kódolt IMPDH szükséges aa lamellociták darázspetéhez történő kitapadásához. Eredmémyeinkből arra következtünk, hogy a raspberry mutációja miatt kevésbé hatékonyan müködnek azok a GTP igényes jelátviteli útvonalak és immunfolyamatok, amelyek a parazitoid darázs pete felismeréséhez és elpusztításához szükségesek. A Drosophila raspberry gén mutációja, illetve az RNS interferencia általi géncsendesítése kedvezőtlenül hathat az általa kódolt IMPDH enzim és ezen keresztül, a GTP molekulák termelődésére, amelyek a hemociták motilitásához és kitapadásához szükséges lamellipódiumok és filopódiumok képződésében nélkülözhetetlen kis GTPázok és G proteinek megfelelő müködéséhez is szükségesek. 


\section{Köszönetnyivánítás}

Köszönettel tartozom Dr. Andó Istvánnak szakmai iránymutatásáért és azért, hogy a csoportjában dolgozhattam. Szeretnék köszönetet mondani témavezetőmnek Dr. Kurucz Évának szakmai irányításáért, a munka minden fázisában nyújtott folyamatos segítségéért, türelméért és támogatásáért.

Köszönönetet mondok minden munkatársamnak, akikkel az évek során egy csoportban

dolgoztam, Csordás Gábornak, Dr. Honti Viktornak, Dr. Zsámboki Jánosnak, Dr. Márkus Róbertnek, Dr. Cinege Gyöngyinek, Lerner Zitának, Gábor Erikának, Varga Gergely Istvánnak a szakmai ségítségükért, hasznos tanácsaikért és barátságukért. Köszönettel tartozom Kovalcsik Olgának, Balázs Anitának, Képiró Anikónak és Tápai Szilviának technikai és emberi segítségnyújtásukért.

Köszönettel tartozom továbbá az SZBK Genetikai Intézet dolgozóinak, valamint a SZBK hatodik emeleti Drosophila közösségének, kiemelelvén Dr. Erdélyi Miklóst, és Dr. Vilmos Pétert, hogy támogatásukkal hozzájárultak a dolgozat létrejöttéhez. Köszönönettel tartozom Dr. Darula Zsuzsannának (MTA SZBK, Tömegspektrometriai Laboratórium) és Kotogány Editnek (MTA SZBK, Áramlási citométer/Sejtszorter Laboratórium).

Köszönetemet szeretném kifejezni opponenseimnek, Dr. Pál Margitnak és Dr. Sinka Ritának, amiért elvállalták PhD dolgozatom bírálatát.

Szeretnék köszönetet mondani egykori gimnáziumi biológia tanáromnak, Leopold Anna Máriának, amiért megkedveltette velem a biológiát, a genetikát.

Végül, de nem utolsósorban szeretném megköszönni családomnak és barátaimnak, hogy támogatták tanulásomat, mindenben számíthattam rájuk, és hogy kitartottak mellettem. 


\section{A dolgozat témájához kapcsolódó közlemények:}

1. Kari B, Zsámboki J, Honti V, Csordás G, Márkus R, Andó I, Kurucz É. 2013. A novel method for the identification of factors involved in host-pathogen interactions in Drosophila melanogaster. J Immunol Methods. 398-399:76-82. IF(2013): 2.225 MTMT: 2463198

2. Kari B, Csordás G, Honti V, Cinege G, Williams MJ, Andó I, Kurucz É. 2016. The raspberry gene is involved in the regulation of the cellular immune response in Drosophila melanogaster. PLoS ONE 11(3): e0150910. doi:10.1371/journal. pone.0150910 $\underline{\mathrm{IF}(2015): 3.54}$ MTMT: 3025315

\section{További közlemények:}

1. Vilmos P, Kristó I, Szikora S, Jankovics F, Lukácsovich T, Kari B, Erdélyi M. 2016. The actin-binding ERM protein Moesin directly regulates spindle assembly and function during mitosis. Cell Biol Int 40(6):696-707. doi: 10.1002/cbin.10607. $\underline{\operatorname{IF}(2015): 1.66}$ MTMT: 3071742

2. Kari B, Zsámboki J, Honti V, Csordás G, Márkus R, Andó I, Kurucz É. 2013. A szeptikus sérülést követő immunválaszt szabályozó genetikai faktorok azonisításának módszerei Drosopholában. Tudomány a vidék mindennapjaiban: Magyar Tudomány Ünnepe. ISBN: 978-963-306-245-6 (Könyvrészlet/Digitális kiadvány magyar nyelven) MTMT: 2519814 